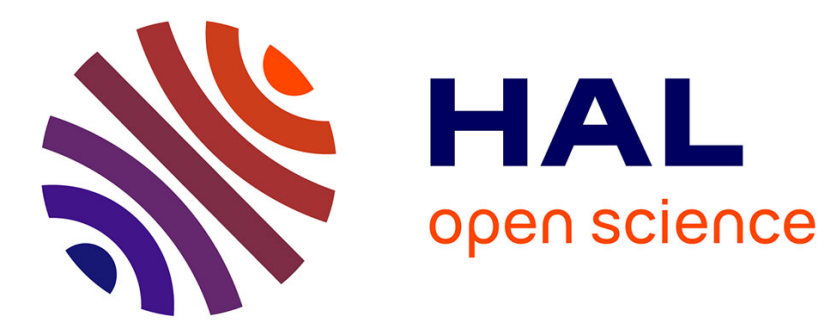

\title{
Quota mobility in the european sugar regime
}

Jean-Christophe Bureau, Herve Guyomard, Laurent Morin, Vincent Requillart

\section{To cite this version:}

Jean-Christophe Bureau, Herve Guyomard, Laurent Morin, Vincent Requillart. Quota mobility in the european sugar regime. 1995, 32 p. hal-01607840

\section{HAL Id: hal-01607840 \\ https://hal.science/hal-01607840}

Submitted on 3 Oct 2017

HAL is a multi-disciplinary open access archive for the deposit and dissemination of scientific research documents, whether they are published or not. The documents may come from teaching and research institutions in France or abroad, or from public or private research centers.
L'archive ouverte pluridisciplinaire HAL, est destinée au dépôt et à la diffusion de documents scientifiques de niveau recherche, publiés ou non, émanant des établissements d'enseignement et de recherche français ou étrangers, des laboratoires publics ou privés.

\section{(a)(1) $\$$}

Distributed under a Creative Commons Attribution - NonCommercial - NoDerivatives 4.0 


\section{包}

TRIENIN I I

Ecole Nationale Supérieure Agronomique

Département Economie, Gestion, Sciences Sociales
Institut National de la Recherche Agronomique Station d'Economie et Sociologie Rurales

\section{QUOTA MOBILITY IN THE EUROPEAN SUGAR REGIME}

Jean-Christophe BUREAU, Hervé GUYOMARD, Laurent MORIN and Vincent REQUILLART 

Jean-Christophe Bureau, Hervé Guyomard, Laurent Morin and Vincent Réquillart

Jean-Christophe Bureau Institut National de la Recherche Agronomique (INRA) de Grignon

Department of Economics Institut National Agronomique Paris-Grignon

78850 Thiverval-Grignon, France

Hervé Guyomard and Laurent Morin Ecole Nationale Supérieure Agronomique de Rennes (ENSAR), and Institut National de la Recherche Agronomique (INRA) de Rennes

Department of Economics

65, rue de Saint-Brieuc 35042 Rennes Cedex, France

Vincent Réquillart Institut National de la Recherche Agronomique (INRA) de Toulouse Department of Economics Université des Sciences Sociales - Manufacture - Batiment F Place Anatole France 31042 Toulouse Cedex, France

Address correspondence to Professor Hervé Guyomard, Ecole Nationale Supérieure Agronomique de Rennes, Département Economie, Gestion et Sciences Sociales, 65 rue de Saint-Brieuc, 35042 Rennes Cedex, France. 


\title{
Quota Mobility in the European Sugar Regime
}

\begin{abstract}
We develop an analytical framework allowing to evaluate the consequences of a market of quota rights in the European Union sugar sector. The three particularities of the sugar regime, i.e., the distinction between "A" and "B" quotas, the levy mechanism and the possibility to produce "C" sugar at world price, are modelled. The empirical objective is to assess how cross-border quota transferability would influence production in the various regions of the European Union. It appears that roughly $46 \%$ of the production could be reallocated. Some of the sugar production is likely to shift from Southern Europe and the Benelux mainly towards France, Germany and Denmark. However, a large amount of transfer would take place between producers of different regions in the same country.
\end{abstract}

Keywords: European Union, sugar, quota, quota market, welfare.

\section{Introduction}

The sugar production in the European Union (EU) has been ruled by the Common Market Organisation (CMO) since 1968. Like most of the agricultural support systems in the EU, the sugar regime relies on institutional support prices. It is however somewhat specific on three points. First, intervention buying is restricted by national quotas. Each Member State allocates its production rights among its processors who contract with farmers to fill the quotas. Farmers can produce beyond their individual quota rights, but sugar produced above quota (known as "C" sugar) is not eligible for intervention buying support. Second, sugar production quotas are split between "A" and "B" quantities. " $A$ " quota production receives the highest level of price support. "B" quota production receives a lower level of support since it is subject to a higher producer levy. Third thus, producer levies are collected to finance the cost of disposing surpluses on third markets so that the system should be self financing and budget neutral. The "A" quota is facing a levy varying between 0 and $2 \%$ of the intervention price, while the "B" quota is facing a higher levy varying between 0 and $39.5 \%$.

Compared to other sectors, the sugar $\mathrm{CMO}$ had not raised many political problems since it has been implemented. A political consensus has kept unchanged the sugar regime for years. It has succeeded in controlling production and avoiding the accumulation of sugar "mountains". Since regulation costs are borne by consumers and producers only, it is more easily accepted than alternative solutions where costs are borne by taxpayers. However, the flaws of the system have recently become more apparent. Some countries have complained that quotas prevent them from using their comparative advantages $^{1}$ (Neff, 1990 ; Agra-Europe London, 1990). Considerable national aids ${ }^{2}$, the agri-monetary system, and shares of production under " $\mathrm{A}$ " quota very variable across countries participate to considerable differences in producer average prices between Member States (Von Cramon-Taubadel, 1990 ; Bureau and Butault, 1992). Many producers consider these price differences as unfair (Confédération Générale de la Betterave, 1987). Consumers also have complained about the high price of sugar in the EU and have shifted to other types of sweeteners, raising questions on the long term sustainability of the regime. A recent report from the European Court of Auditors (ECA, 1991) has fuelled these long lasting criticisms, and has described the regime as a being against the principle of a single 
market. The report called for major changes in the EU sugar regime in order to increase the efficiency of the sugar sector and lower the costs borne by consumers.

A first step towards a more efficient sugar sector requires to suppress national aids and other distortions from the principle of a "common market" which create incentives to production in high cost areas. A further step requires changes in the quota system.

Alston (1981) showed clearly how imperfectly transferable quotas induce shifts in aggregate supply as well as movements along aggregate supply function. He highlights the nature of these shifts (imperfect quota allocation, technical change, uncertainty and externalities) and concludes that transferable quotas are preferable to non transferable quotas in order to minimise the size of the changes in supply and the associated social costs. As it is well known, there is room for mutually beneficial exchange of quotas between producers as long as there remain differences in marginal costs (see, for example, Butcher and Heady, 1963 ; Cox, 1987 ; Burrell, 1989 ; Rucker et al., 1993). Producers with highest marginal costs at the regulated output level will offer quantities as long as the quota price is higher than their unit quasi rent. Similarly, low marginal cost producers will demand quota rights at decreasing prices. At the equilibrium price for quota rights, unit quasi rents are equalised across farms, marginal costs are the same (if all farms face the same output price) and equal to the industry marginal cost. In other words, free trading of quotas minimises the cost of producing the aggregate quota level. Consequently, non transferable quotas lead to inefficiencies and higher production costs than necessary, and prevent a reallocation of production across regions more conform to comparative advantages.

As there seems to be a political consensus for maintaining a supply control for sugar in the EU, we do not investigate the effects of a suppression of the quota regime in this paper. We focus instead on the effects of a leasing quota market. Section 2 summarises some economic aspects of production under quota and analyses the effects of a competitive market of production rights for sugar in the EU. The analytical framework takes into account the three particularities of the EU sugar quota regime, i.e., the distinction between "A" and "B" quotas, the levy mechanism and the possibility for each farmer to produce "C" sugar at world price. Section 3 provides some empirical estimates of the magnitude of transfers and producer welfare gains associated with the implementation of an European leasing quota market for sugar. Section 4 concludes.

\section{Economic aspects of sugar quota transfer in the EU}

i) basic principles of quota mobility

There is a broad consensus, at least among economists, that transferable quotas are more efficient that non transferable quotas because transferable quotas allow production costs to be minimised and hence, producers gains to be maximised (for a given product price and for a given global quota). Clear discussions of the non optimality of restricting the transfer of production rights are presented in 
Butcher and Heady (1963), Alston (1981, 1992), Burrell (1989), or Rucker et al. (1993), for example. The basic idea is that a limitation of the production for all producers generates a welfare loss when their marginal costs are heterogeneous. Efficient producers cannot produce extra quantities at a low marginal cost, while poorly efficient producers are allowed to produce their last units at a high marginal cost. The society would be better off if low marginal cost producers could produce a little more and high marginal cost producers a little less.

Microeconomics of supply under quota is well documented in the literature. Moschini (1988, 1989), Squires (1992), Fulginiti and Perrin (1993), and Guyomard and Mahé (1993), for example, provide a clear presentation of the modelling of technology under quota. Montgomery (1972), Burrell (1989), Babcock and Foster (1992), and Rucker et al. (1993), for example, discuss the economics of a competitive market for quotas. Their analysis may be summarised as follows.

Consider a profit maximising farmer $n, \quad n=1, \ldots, N$, who produces the output $y^{n}$ according to the well-behaved cost structure $C^{n}\left(y^{n}, w, \bar{Z}^{n}\right)$ where $w$ is the market price vector of variable input quantities $x^{n}$ (raw materials) and $\bar{Z}^{n}$ is the quasi-fixed factor quantity vector (capital, land and labour). The farmer is a price-taker in the output and variable input markets. Output $y^{n}$ is constrained by an individual quota at level $\bar{y}^{n}$ and quotas can be freely traded among producers for one production cycle. Let $r$ be the rental price of quota. The farmer's behaviour in this regime of tradable quota rights is summarised by the following programme ${ }^{3}$ :

(1) $\max _{y^{n}, q^{n}}\left[\pi=p y^{n}-C^{n}\left(y^{n}, w, \bar{Z}^{n}\right)-r q^{n} ; y^{n}=\bar{y}^{n}+q^{n}\right] \equiv \pi^{n}\left(p-r, w, \bar{Z}^{n}\right)+r \bar{y}^{n}$

where $r q^{n} \geq 0$ represents the cost of leasing additional quota $q^{n}$ at a price $r$ and $r q^{n} \leq 0$ represents the earnings from leasing out part or all of initial quota, also at a price $r$ per unit. $\pi^{n}\left(p-r, w, \bar{Z}^{n}\right)$ is the short-run unrationed profit function corresponding to the no-quota regime and defined by:

(2) $\max _{y^{n}}\left[\pi=(p-r) y^{n}-C^{n}\left(y^{n}, w, \bar{Z}^{n}\right)\right] \equiv \pi^{n}\left(p-r, w, \bar{Z}^{n}\right)$

There is room for mutually beneficial exchange of quota between producers as long as there remain differences in marginal costs: producer $n$ will lease additional quota if his marginal cost is lower than the difference $p-r$ and he will lease out part or all of his initial quota endowment if his marginal cost is greater than $p-r$. Quota will be exchanged until the marginal costs of production of all firms are equalised (see, e.g., Butcher and Heady, 1963 ; Moschini, 1984 ; Cox, 1987 ; Babcock and Foster, 1992 ; Guyomard et al., 1994), i.e.,

(3) $\partial C^{n}\left(y^{\prime, n}, w, \bar{Z}^{n}\right) / \partial y=p-r \quad \forall n \in N$ 
where $y^{t, n}$ represents the optimal level of output in the regime of tradable rights.

Equation (3) implicitly defines the output supply function $y^{t . n}\left(p-r, w, \bar{Z}^{n}\right)$ which can also directly be derived from the short-run unrationed profit function, evaluated at price $p-r$, by Hotelling's lemma:

(4) $y^{t, n}\left(p-r, w, \bar{Z}^{n}\right)=\partial \pi^{n}\left(p-r, w, \bar{Z}^{n}\right) / \partial p \quad \forall n \in N$

Competitive market equilibrium for quota rights is defined by a quota rental price $r^{*}$ such that the quota market clears, i.e., a rental price $r^{*}$ where the industry excess demand for quota rights is brought to zero:

(5) $\sum_{n=1}^{N} q^{t, n}\left(p-r^{*}, w, \bar{Z}^{n}, \bar{y}^{n}\right)=\sum_{n=1}^{N} y^{t, n}\left(p-r^{*}, w, \bar{Z}^{n}\right)-\sum_{n=1}^{N} \bar{y}^{n}=0$

Equation (5), solved for $r$, defines the equilibrium rental price $r^{*}$ of the quota as a function of exogenous variables, i.e., $\bar{y}^{n}, p, w, \bar{Z}^{n}$ and $N$. The comparative statics of this equilibrium rental price $r^{*}$ is obtained by total differentiating of (5) and solving for $d r^{*}$ :

(6) $d r^{*}=d p-\left(\sum_{N} \pi_{p p}^{n}\right)^{-1}\left(\sum_{N} d \bar{y}^{n}-\sum_{N} \pi_{p w}^{n} d w-\sum_{N} \pi_{p z}^{n} d \bar{Z}^{n}\right)$

Equation (6) shows that the equilibrium rental price, i) absorbs any change in the output price $\left(\partial r^{*} / \partial p=1\right)$, ii) is decreasing in the aggregate quota level, iii) is decreasing in the prices of non inferior variable inputs, and iv) is increasing in the quantities of non inferior quasi-fixed factors ${ }^{4}$. Furthermore, it is worth noting that the equilibrium rental price does not depend on individual quota endowments $\bar{y}^{n}$, but on the aggregate quota level $\bar{Y}$.

The market for quota rights is illustrated by Figure 1, panels $a, b$ and $c$, in the case of two producers initially granted at levels $\bar{y}^{l}$ and $\bar{y}^{2}$. Panel a illustrates the situation at the firm level, panel $\mathrm{b}$ depicts the quota market and panel c corresponds to the analysis at the industry level on the basis of aggregate supply curves of the product. Given the initial distribution of quotas and the position of marginal cost curves, the two producers will benefit from exchanging quantities since their marginal cost differ $\left(p-r^{1}\right.$ and $p-r^{2}$, respectively). For a quota price $r$ greater than $r^{1}$ and smaller than $r^{2}$, high marginal cost producer one is willing to lease out quotas and low marginal cost producer two is willing to rent additional references. The equilibrium rental rate is obtained when supply and demand for quota rights balance. On this two-producer example, the supply function of quota is simply a part of the marginal cost function of producer one while the demand function of quota is a part of the marginal cost function of producer two. They are noted $S$ and $D$, respectively, and are depicted on panel b. 
The intersection of quota supply and demand curves determines the equilibrium price $r^{*}$ and traded quantity $Q^{*}$ which correspond to point $E$. With respect to the non tradable quota regime, quota sellers' welfare increases by area $A$ and quota purchasers' welfare increases by area $B$. These welfare gains may equivalently be measured at the firm level (panel a) or at the industry level (panel c).

\section{(insert Figure 1, panels $a, b$ and $c$ )}

ii) application to the EU sugar regime

In the case of sugar, individual rights have been allocated on the basis of past references. In the present regime, they are not transferable unless one trades the land associated to quotas, and it is almost impossible for newcomers to enter production. Since efficient production is curtailed at the expense of some relatively less efficient production, this generates the welfare loss described above, welfare loss which should be eliminated by allowing quotas to be traded. However, two particular features of the EU sugar regime have to be taken into account in order to apply the preceding theoretical framework for analysing the consequences of a market of production rights on sugar beets: i) the distinction between "A" and "B" quotas, and ii) the possibility for each farmer to produce " $\mathrm{C}$ " sugar at world price. The sugar producer's programme in the regime of tradable quota rights may then be written as ${ }^{5}$ :

$$
\begin{aligned}
& \max _{y_{a}^{n}, y_{b}^{n}, y_{c}^{n}}\left[\pi=\left(p_{a}-r_{a}\right) y_{a}^{n}+\left(p_{b}-r_{b}\right) y_{b}^{n}+p_{c} y_{c}^{n}-C^{n}\left(y^{n}=y_{a}^{n}+y_{b}^{n}+y_{c}^{n}, w, \bar{Z}^{n}\right) ; y_{a}^{n} \geq 0 ; y_{b}^{n} \geq 0 ;\right. \\
& \left.y_{c}^{n} \geq 0\right]+r_{a} \bar{y}_{a}^{n}+r_{b} \bar{y}_{b}^{n}
\end{aligned}
$$

where $y_{a}^{n}$ is "A" sugar quantity (output price $p_{a}$ and quota rental price $r_{a}$ ), $y_{b}^{n}$ is "B" sugar quantity (output price $p_{b}$ and quota rental price $r_{h}$ ), and $y_{c}^{n}$ is "C" sugar produced at world price $p_{c}$. "A" and "B" quota initial quantities are noted $\bar{y}_{a}^{n}$ and $\bar{y}_{b}^{n}$, respectively.

The first-order necessary conditions for programme (7) are (the two rental prices are assumed to be strictly positive):

(8a) $p_{a}-r_{a}-C m^{n}\left(y^{t, n}\right)+\delta_{a}^{n}=0$

(8b) $p_{b}-r_{b}-C m^{n}\left(y^{\prime \prime n}\right)+\delta_{b}^{n}=0$

(8c) $p_{c}-C m^{n}\left(y^{t, n}\right)+\delta_{c}^{n}=0$

(8d) $y_{i}^{\prime, n} \delta_{i}^{n}=0 ; y_{i}^{\prime, n} \geq 0, \delta_{i}^{n} \geq 0 ; i=a, b, c$

where $y^{t, n}=y_{a}^{t, n}+y_{b}^{t, n}+y_{c}^{t, n}$ represents the optimal level of production in the regime of tradable rights, and $\delta_{a}^{n}, \delta_{b}^{n}$, and $\delta_{c}^{n}$ are the Lagrange multipliers associated with non-negativity constraints on 
"A", "B" and "C" sugar, respectively. We note $\mathrm{Cm}^{n}\left(y^{t . n}\right)$ the marginal cost of producing the quantity $y_{n}^{l, n}$.

Three conditions which are verified at quota market equilibrium allows us to simplify the analysis. These three conditions are shown in Annex 1 and may be summarised as follows: if " $A$ " and "B" quotas are constraining for each producer $n$, equilibrium quota rental prices $r_{a}^{*}$ and $r_{b}^{*}$ should verify: i) $p_{a}-p_{b}<r_{a}^{*}$, ii) $p_{a}-p_{b}=r_{a}^{*}-r_{b}^{*}$, and iii) $p_{a}-r_{a}^{*}=p_{b}-r_{b}^{*} \geq p_{c}$. Condition ii) is particularly useful since it allows us to analyse the quota market by considering that there is only "B" sugar paid at price $p_{b}{ }^{6}$. In total, seven "behaviours" have thus to be distinguished, "behaviours" which correspond to seven producer categories. They are summarised in Table 1 and are defined below. These seven producer categories are grouped into three main classes which are defined by the relative positions of the marginal cost of producing a zero level of output (i.e., $\mathrm{Cm}^{n}(0)$ ), of the marginal cost of producing the quota level (i.e., $\mathrm{Cm}^{n}\left(\bar{y}_{a}+\bar{y}_{b}\right)$ ), and of the world price of sugar (i.e., $p_{c}$ ). We note $N_{i, j}$ the number of producers who belong to the category $i, j$ where $i \quad(i=1, \ldots, 3)$ refers to the class and $j$ to a given behaviour in this class.

\section{(insert Table 1)}

a) For the producers of the first class, $\mathrm{Cm}^{\prime \prime}(0) \geq p_{c}$. The marginal cost of producing a zero level of output, and a fortiori a positive level of output, is always greater or equal than the world price of sugar. There does not exist a strictly positive production level $y^{n}$ such that $C m^{n}\left(y^{n}\right)=p_{c}$, and hence $\delta_{n}^{c}>0$. In other words, the farmer did not produce " $\mathrm{C}$ " sugar in the non tradable quota regime and will not produce " $\mathrm{C}$ " sugar in the tradable quota regime. If $p_{b}-r_{b} \leq \mathrm{Cm}^{n}(0)$, the farmer leases out all of his initial endowment and becomes a full "renter". Let $\eta^{n}$ be the marginal cost of production at "A+B" quota level, i.e., $\eta^{n}=C m^{n}\left(\bar{y}_{a}^{n}+\bar{y}_{h}^{n}\right)$. If $C m^{n}(0) \leq p_{b}-r_{h} \leq \eta^{n}$, i.e., if the market rental price of quota is greater than the unit quasi rent, the farmer leases out a part of his initial endowment up to the production level $y^{t, n}$ where his marginal cost $C m^{n}\left(y^{t, n}\right)$ equals the difference $p_{b}-r_{b}$. If $\mathrm{Cm}^{n}(0) \leq \eta^{n} \leq p_{b}-r_{b}$, i.e., if the market rental price of quota is lower than the unit quasi rent, he rents additional " $A+B$ " quantities up to the amount where his marginal cost equals the difference $p_{h}-r_{h}$.

b) For the producers of the second class, $\mathrm{Cm}^{n}(0) \leq p_{c} \leq C m^{n}\left(\bar{y}_{a}^{n}+\bar{y}_{b}^{n}\right)=\eta^{n}$. It is unprofitable for these farmers to produce " $\mathrm{C}$ " sugar in the non tradable quota regime. If $p_{c} \leq p_{b}-r_{b} \leq \eta^{n}$, it is still unprofitable to produce " $\mathrm{C}$ " sugar in the tradable quota regime, $y_{a+h}^{t, n}$ is lower than $\bar{y}_{a+h}^{n}$ and the farmer leases out quota rights so that his marginal cost is just $p_{b}-r_{b}$. If $p_{c} \leq \eta^{\prime \prime} \leq p_{b}-r_{b}$, it is also 
unprofitable to produce " $\mathrm{C}$ " sugar in the tradable quota regime, $y_{a+h}^{t, n}$ is greater than $\bar{y}_{a+b}^{n}$ and the farmer rents additional quota rights so that his marginal cost equals $p_{b}-r_{b}$.

c) For the producers of the third class, $\mathrm{Cm}^{n}(0) \leq C m^{n}\left(\bar{y}_{a}^{n}+\bar{y}_{b}^{n}\right)=\eta^{n} \leq C m^{n}\left(\bar{y}_{a}^{n}+\bar{y}_{b}^{n}+y_{c}^{n}\right)=p_{c}$. The " $C$ " sugar quantity which was profitable to produce in the non tradable quota regime was solution in $y_{c}^{n}$ of the equality equation between marginal cost of production and world price, i.e., $C m^{n}\left(\bar{y}_{a}^{n}+\bar{y}_{b}^{n}+y_{c}^{n}\right)=p_{c}$. If $p_{b}-r_{b}>C^{n}\left(\bar{y}_{a}^{n}+\bar{y}_{b}^{n}+y_{c}^{n}\right)=p_{c}$, the producer will rent additional "A+B" quota rights up the amount $q_{a+b}^{t, n}=y_{a+h}^{t, n}-\bar{y}_{a+b}^{n}$. He does no more produce "C" quantities and prefers to rent " $\mathrm{A}+\mathrm{B}$ " quantities for a equivalent amount. Since $p_{b}-r_{b}>p_{c}$, his final production level is greater than his initial production. If $p_{b}-r_{b}=C m^{n}\left(\bar{y}_{a}^{n}+\bar{y}_{b}^{n}+y_{c}^{n}\right)=p_{c}$, the producer is indifferent between producing " $\mathrm{C}$ " sugar or renting additional " $\mathrm{A}+\mathrm{B}$ " quotas for an equivalent amount.

Competitive market equilibrium for quota rights is defined by a quota rental price such that the quota market clears. Let us first assume that the world price of sugar $p_{c}$ is low enough so that " $\mathrm{C}$ " sugar quantities equal zero in the non tradable quota regime. In such a case, $N_{3 .}=0$ and the quota market equilibrium equation reduces to:

(9)

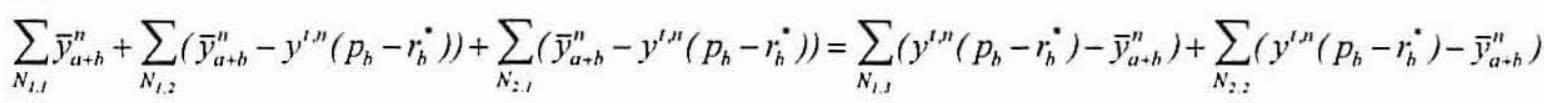

This situation corresponds to the "standard" model depicted by Figure 1 since no "C" sugar is produced, either before the quota market or after it has been implemented. The intersection of industry supply and demand curves at point $E$ determines the equilibrium rental price $r_{b}^{*}=r^{*}$ and exchanged quantity $Q^{*}$. Sellers' welfare increases by area $A$ and purchasers' welfare increases by area $B$.

If the world price of sugar increases, some producers shift from the $N_{2}$ group to the $N_{3}$ group, i.e., it becomes profitable for some farmers to produce some " $\mathrm{C}$ " sugar quantities in the non tradable quota regime. As long as the world price of sugar $p_{c}$ remains strictly lower than the difference $p_{b}-r_{b}^{*}$, there is always room for mutually (i.e., for renters out and for renters in) beneficial exchange of production rights. The quota market equilibrium remains at point $E$ where supply and demand for quota rights balance (equilibrium rental price $r_{h}^{*}$ and exchanged quantity $Q^{*}$ ). Furthermore, production of "C" sugar is now zero. Quota sellers' welfare increases by area $A$, but purchaser's welfare increases by a smaller amount corresponding to hatched area $C$ on Figure 2

\section{(insert Figure 2)}


Let us now assume that the world price of sugar increases up to the level $p_{b}-r_{b}^{*}$. In such a case, producers of the $N_{3}$ group are indifferent between renting additional references or producing the same quantity at world price (i.e., as "C" sugar). For a quota market equilibrium to occur, we assume that producers of the $N_{3}$ will choose to rent "A+B" quotas corresponding to the quantity suppliers are willing to rent out at price $p_{b}-r_{h}^{*}=p_{c}$. Again equilibrium occurs at point $E$. Sellers' welfare increases by area $A$, but purchaser's welfare is now unchanged with respect to the non tradable quota regime.

Finally, if the world price of sugar becomes greater than $p_{b}-r_{b}^{*}$, quota market equilibrium no more occurs at point $E$ since it becomes more profitable for members of the $N_{3}$ group to produce at marginal cost $p_{c}$ instead of $p_{b}-r_{b}^{*}<p_{c}$. Consequently, the new equilibrium rental price $r_{b}^{*}$ adjusts downward to the new world price. At equilibrium, it is equal to the difference $p_{b}-p_{c}<r_{b}^{*}$. It corresponds to point $F$ on Figure 3 where supply of quota rights equals $Q^{* *}$ and sellers' welfare gain is limited to area $D$. It is worth remembering that potential purchasers are indifferent between renting " $\mathrm{A}+\mathrm{B}$ " quotas or producing " $\mathrm{C}$ " sugar quantities for the same amount, and that we assume that these purchasers "choose" to rent in " $A+B$ " quotas instead of producing " $C$ " sugar.

\section{(insert Figure 3)}

\section{iii) producers' welfare gain with an inter-regional market of sugar production rights}

When quotas are made transferable through a competitive market, the increase in producers' global welfare is the sum of the surplus changes of net quota suppliers $W_{s}$ and the surplus variations of net quota purchasers $W_{d}$. This global welfare gain is represented by the sum of the hatched areas in Figures 1,2 or 3 . In the empirical application, we consider the case where producers in region $j$ are allowed to trade individual quota rights with producers in other regions. In such a case, a competitive market of quota in the entire EU exhausts the sum of all dead-weight losses across regions, but the equilibrium quota rental price does not necessarily clear the quota market in each region separately.

The aggregate regional supply and demand functions of sugar quotas in region $j$ are noted $S_{j}\left(r_{b}\right)$ and $D_{j}\left(r_{b}\right)$, respectively. They may be defined as follows:

$$
\begin{aligned}
& S_{j}\left(r_{b}\right)=\sum_{\text {supp pliers of }}\left(\bar{y}_{\text {region } j}^{n}-y_{a+b}^{\prime, n}\left(p_{b}-r_{b}\right)\right)
\end{aligned}
$$

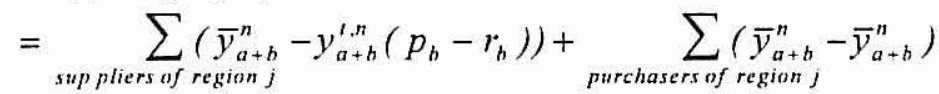

$$
\begin{aligned}
& =\bar{Y}_{a+h}^{j}-\sum_{\text {producers of region } j} \min _{a+b}\left(\bar{y}_{a+b}^{n}, y_{a+b}^{t, n}\left(p_{b}-r_{b}\right)\right) \\
& =\bar{Y}_{a+b}^{j}-F_{c}^{j}\left(p_{b}-r_{b}\right)
\end{aligned}
$$




$$
\begin{aligned}
& D_{j}\left(r_{h}\right)=\sum_{\text {purcahsers of }}\left(y_{a c \text { gion } j}^{\prime, n}\left(p_{b}-r_{b}\right)-\bar{y}_{a+b}^{n}\right) \\
& =\sum_{\text {purchasers of }}\left(y_{\text {region } j}^{t, n}\left(p_{h}-r_{b}\right)-\bar{y}_{a+b}^{n}\right)+\sum_{\text {sup pliers of region }}\left(y_{a+b}^{t, n}\left(p_{h}-r_{b}\right)-y_{a+b}^{t, n}\left(p_{b}-r_{b}\right)\right) \\
& =\sum_{\text {producers of region } j}\left(y_{b}^{\prime, n}\left(r_{b}\right)\right)-\sum_{\text {producers of region } j} \min \left(\bar{y}_{a+b}^{n}, y_{a+h}^{t, n}\left(p_{b}-r_{b}\right)\right) \\
& =F_{u}{ }^{j}\left(p_{b}-r_{b}\right)-F_{c}{ }^{j}\left(p_{b}-r_{b}\right)
\end{aligned}
$$

where $F_{c}^{j}($.) is the constrained aggregate supply function of sugar beets in region $j$ when production is restricted by quotas, $F_{u}^{j}($.$) is the unconstrained aggregate supply function of sugar beets in region j$ if production is not constrained by quotas, and $\bar{Y}_{a+b}^{j}$ is the aggregate quota level in region $j$.

The surplus variations for producers of a particular region $j$ due to the implementation of the quota market at the EU scale are then the following ${ }^{7}$ :

(11a) $W_{s}^{j}\left(r_{b}\right)=\int_{F_{c}^{j}\left(p_{\mathrm{b}}-r_{b}\right)}^{\bar{\Gamma}_{a}^{j}}\left(F_{c}^{j}\right)^{-1}(t) d t-\left(p_{b}-r_{b}\right)\left(\bar{Y}_{a+b}^{j}-F_{c}^{j}\left(p_{b}-r_{b}\right)\right)$

$$
\begin{aligned}
W_{d}^{j}\left(r_{h}\right)= & \int_{0}^{F_{c}^{\prime}\left(p_{b}-r_{h}\right)}\left(F_{c}^{j}\right)^{-1}(t) d t-\int_{0}^{F_{u}^{j}\left(p_{b}-r_{b}\right)}\left(F_{u}^{j}\right)^{-1}(t) d t+\left(p_{b}-r_{b}\right)\left(F_{u}^{j}\left(p_{b}-r_{b}\right)-F_{c}^{j}\left(p_{b}-r_{b}\right)\right) \\
& -\left(\int_{0}^{F_{c}^{\prime}\left(p_{c}\right)}\left(F_{c}^{j}\right)^{-1}(t) d t-\int_{0}^{F_{u}^{j}\left(p_{c}\right)}\left(F_{u}^{j}\right)^{-1}(t) d t+\left(p_{c}\right)\left(F_{u}^{j}\left(p_{c}\right)-F_{c}^{j}\left(p_{c}\right)\right)\right)
\end{aligned}
$$

These producers' surplus variations are illustrated by Figure 4 for a given region $j$. Let us first assume that the equilibrium quota price $r_{b}^{*}$ (defined on all regions) is lower than the difference $p_{b}-p_{c}$. The equilibrium quota price does balance supply and demand of quota in the EU but not necessarily in each region, and particularly in region $j$. In effect, on Figure 4 , the quota supply of region $j$ is equal to $Q^{S . j}=\bar{Y}_{a+h}^{j}-F_{c}^{j}\left(p_{b}-r_{b}^{*}\right)$, but the quota demand of region $j$ is $Q^{D, j}=F_{u}^{j}\left(p_{b}-r_{b}^{*}\right)-F_{c}^{j}\left(p_{b}-r_{b}^{*}\right)$ which is greater than the corresponding supply. Sellers' welfare increases by area $a b c$ while purchasers' welfare increases by area $a d e f$. Area $f e g$, which corresponds to the welfare gain due to " $C$ " sugar produced by low marginal cost producers, has not to be taken into account in the evaluation of the purchasers' welfare gain. Let us now assume that the world price increases up the level $\hat{p}_{c}=p_{b}-r_{b}^{*}$. In that case, one easily verifies that sellers' welfare still increases by area $a b c$ but that purchasers' welfare is unchanged with respect to the non tradable quota regime.

\section{(insert Figure 4)}

Empirical estimations of producers' welfare gains (11a) and (11b) will be presented in section 3. The sum of $W_{s}^{j}$ and $W_{d}^{j}$ measures the welfare change for the producers of region $j$ that are generated 
by the implementation of a market of individual production rights common to all EU regions. It gives an estimate of the dead-weight loss due to the non tradable quota system.

\section{Empirical application}

This section illustrates the effects of implementing a competitive leasing market of sugar quota at the EU scale. In section 2, we have shown that such a market should be modelled conditionally to the level of the world price of sugar. Therefore, we characterise the leasing quota market at equilibrium for different levels of the world price of sugar.

Annex 2 describes the approach followed to estimate unconstrained and constrained regional supply functions of sugar, $F_{u}^{j}\left(\right.$.) and $F_{c}^{j}($.), respectively, on the basis of available information. These functions are used to evaluate opportunity costs of marginal sugar beet production for the firms of the different European regions. According to their opportunity costs and the prices of sugar, farmers decide to lease in or out some sugar quota. The clearing of the market across regions leads to an equilibrium lease

rate $r_{a}^{*}$ (or $r_{a}^{*}$ ) for "A" quota and $r_{b}^{*}$ (or $r_{b}$ ) for "B" quota. Quantities exchanged across regions and producer welfare changes in each region may then be evaluated. At this stage, two remarks are in order. First, in the empirical model, a regional processing capacity constraint is imposed on the total quantity of sugar a given region can produce. In other words, we simulate the effects of the quota market under the constraint $F_{j}^{\prime \prime}($. $) \leq K_{j}$ where $K_{j}$ is the capacity constraint for region $j^{9}$. Therefore, even if a region $j$ has a substantial comparative advantage with respect to other regions, farmers in region $j$ cannot purchase more quotas than the total capacity of sugar refineries of the region. Second, the price received by producers includes national aids as well as regional price variations.

Table 2 shows average opportunity cost of sugar beet for the various producing regions of the EU distinguished in the model. These regions account for roughly 90 percent of the total European beet production.

The opportunity cost of sugar is an indicator of the willingness of the firm to purchase or sale quota rights, when facing a given market price for quotas. It contains all the information on production costs, on profitability of alternative crops and on the ability to expand sugar production on the farm, ability which may be limited by technical constraints (for more details on this point, see Annex 2). Although there are large variations within the same region, figures in Table 2 suggest that French and German regions are, in general, keen on expanding their production. Producers in these areas have a low opportunity cost and hence, are willing to pay a relatively high price for being allowed to produce extra sugar beets. The willingness to pay for extra quota rights is lower in Italian and Spanish regions. It is noteworthy that opportunity costs are often quite high in regions where beets account for a small share of the cultivated land (column 3 of Table 2). This suggests that sugar quotas have been initially allocated to the different regions regardless of the competitiveness of the region. This also emphasises the interest for a market of 
quota rights at the EU scale which may lead to a reallocation of production more consistent with comparative advantages.

\section{(insert Table 2)}

Table 3 presents the producer prices of "A" and "B" beets ${ }^{10}$ and the equilibrium rental rates of " $A$ " and "B" quotas in four situations corresponding to four assumptions on the world price level $(13.5,22.5$, 29.0 and 30.5 ECU per tonne, respectively). The intervention price is given at 45.4 ECU per tonne. Producer prices are then equal to the intervention price minus the relevant levies. Levies on "A" and "B" quotas are calculated to exactly compensate the cost of export refunds. In the four cases considered in the paper, the "A" quota is facing a fixed levy equal to $2 \%$ of the intervention price while the "B" sugar is facing a higher levy varying between 4.62 and $32.16 \%$. The price of " $\mathrm{A}$ " sugar is not affected by world price changes because the levy decreases and is lower than $2 \%$ only for very high levels of the world price, namely much higher than $30.5 \mathrm{ECU}$ per tonne. In contrast, the price of "B" sugar is very sensitive to variations of the world price because "B" sugar bears the largest part of the cost of export refunds. An increase in the world price lowers the level of refunds and hence leads to an increase in the price of "B" sugar.

Table 3 allows us to evaluate the effects of an increase in the world price of sugar on "A" and "B" quota rental rates. For a world price of sugar beet of 13.5 ECU per tonne, " $\mathrm{A}$ " and "B" equilibrium quota rental rates are equal to 15.3 and 1.6 ECU per tonne, respectively. As long as the difference $p_{a}-r_{a}^{*}=p_{b}-r_{b}^{*}$ remains greater than $p_{c}$, i.e., $p_{c}$ lower than $29.0 \mathrm{ECU}$ per tonne in Table 3 , the rental rate $r_{a}^{*}$ remains unchanged while the rental rate $r_{b}^{*}$ adjusts upward because a higher world price induces an increases in the price of "B" sugar. For high levels of the world price, i.e., $p_{c}$ strictly greater than 29.0 ECU per tonne in Table 3 , both rental rates adjust downwards to the level where $p_{a}-r_{a}^{\ddot{*}}=p_{b}-r_{b} \ddot{*}=p_{c}{ }^{11}$. Although both the level of "A" quota and the price of "A" sugar remain unchanged, the lease rate of " $\mathrm{A}$ " quota is also an increasing function of the world price of sugar beet when the latter exceeds a certain threshold, namely 29.0 ECU per tonne in Table 3.

According to the simulation results presented in Table 3, it appears that the equilibrium rental rate of " $\mathrm{A}$ " sugar is roughly equal to 34 percent of the price of " $\mathrm{A}$ " sugar for any level of the world price ranking between the plausible values of the table. This relatively high value of the quota traded on the market suggests that the support to sugar producers is likely to capitalise in the quota asset under a market of tradable rights. Under the present situation, this support already capitalises into land prices of farms benefiting from quotas (on this point, see Floyd, 1965).

\section{(insert Table 3)}

Table 4 presents the reallocation effects of the quota market at the country level for the four scenarii corresponding to the four assumptions on the world price. Figures are obtained by summing up 
the net supply and demand of quotas for all the regions in each country. The amount of quota rights traded is considerable since it represents roughly $45 \%$ of the global quota for the whole of the EU. As long as $p_{c}<p_{a}-r_{a}^{*}=p_{b}-r_{b}^{*}$ (i.e., for the first three columns of Table 4), quantity exchanged between farms amounts to roughly 5 million tonnes. Half of this quantity is traded between farms of the same region while the second half is reallocated to different regions. Four countries are net purchasers of quota rights (Denmark, Germany, France, and the United Kingdom) while other countries are net sellers, particularly those of the Southern part of the EU.

Several factors contribute to determine if a given region will be a net seller or buyer of quota: the (marginal) cost of beet production (i.e., the competitiveness of the region), the "potential" for an increase in output defined as the gap between the unconstrained and constrained supply curves (see Figure 3 ) and the producer price (producer prices vary between regions because of national aids, regional prices and monetary effects). Accordingly, although many Belgian producers are efficient, Belgium would be a net seller of quota if an European market of quota rights would be implemented. The reason is that beets already account for a large share of arable land in the most efficient farms. Farmers who would be net buyers of quota have thus a relatively small margin for increasing their production. At the national level, the magnitude of the purchase of quota does not compensate for the selling of quota rights by the less efficient farmers of the country. On contrary, there is a potential for increasing beet production without hitting technical constraints in France. Many French farms therefore combine low production costs with non binding technical constraints. In spite of a processing constraint in several French regions, the national demand for quota exceeds the supply, and France would be a net buyer of quota rights on the market.

The effects of the quota market on "C" sugar production vary with the level of the world price. As long as $p_{c}$ is lower than $p_{a}-r_{a}^{*}=p_{b}-r_{b}^{*}$ (i.e., $p_{c} \leq 29.0 \mathrm{ECU}$ per tonne in Table 4), a collapse of the production of " $C$ " sugar follows the implementation of the quota market. For low levels of the world price, it is more profitable to rent extra quotas than to produce " $\mathrm{C}$ " sugar. This result is illustrated, for example, by the case where the world price of sugar is $22.5 \mathrm{ECU}$ per tonne (second column of Table 4). For this particular value of $p_{c}$, the production of $C$ sugar (1899 million tonnes under the present scheme) becomes zero after the implementation of the quota market. In other words, for low levels of the world price, a market for quota rights leads to a decrease in total production because the most efficient producers would substitute " $\mathrm{A}$ " and "B" sugar to the $\mathrm{C}$ sugar thanks to the ability to purchase extra " $\mathrm{A}$ " and "B" quota rights. For high levels of the world price (i.e., when $p_{c}>29.0 \mathrm{ECU}$ per tonne, e.g., when $p_{c}=30.5 \mathrm{ECU}$ per tonne in Table 4), the amount of quota rights traded decreases since both equilibrium lease rates $r_{a}^{*}$ and $r_{b}^{*}$ adjust downwards. The quantity of "C" sugar sold on the world market is now positive although it is lower than in the absence of the quota market. It is worth remembering that a 
producer is indifferent (in a world without uncertainty) to produce "A", "B" or "C" sugar because $p_{a}-r_{a}^{\ddot{*}}=p_{b}-r_{b}^{*}=p_{c}$.

\section{(insert Table 4)}

Table 5 shows the effects of the quota market on producers' welfare, be they buyers or sellers. Clearly, producers' surplus variations are a function of the world price which affects equilibrium rental rates, quota quantity traded and initial producers' surpluses. For low levels of the world price (e.g., $p_{c}=$ 13.5 ECU per tonne in Table 5), there is no " $\mathrm{C}$ " sugar in the non tradable quota regime. In such a case, the market for quota rights generates large welfare gains for producers (buyers and sellers) who are now allowed to trade quotas. The increase in the surplus of quota sellers amounts to 65 million ECU while the increase in the surplus of quota buyers amounts to 30.7 million ECU. A part of these welfare gains comes from the selling of quotas by producers who did not produce up to their quota right. Therefore, the market for quotas creates a valuable asset from unused production rights. When the world price of sugar increases, the initial producers' surplus increases too because the production of " $\mathrm{C}$ " sugar is now positive. For intermediate levels of the world price up to $p_{a}-r_{a}^{*}=p_{b}-r_{b}^{*}=29.0 \mathrm{ECU}$ per tonne (e.g., $p_{c}=22.5$ ECU per tonne in Table 5), the surplus gain of quota buyers decreases while the surplus gain of quota sellers remains virtually unchanged (it slightly decreases in \%). The surplus gain of buyers is a decreasing function of the world price and becomes zero when $p_{c}=p_{a}-r_{a}^{*}=p_{b}-r_{b}^{*}$, i.e., when the world price of sugar reaches the "effective" price of sugar beet in a tradable quota regime (i.e., $29.0 \mathrm{ECU}$ per tonne in Table 5). For higher levels of the world price (e.g., 30.5 ECU per tonne in Table 5), the equilibrium lease rate of "A" quota also decreases as well as the surplus gain of quota buyers.

\section{(insert Table 5)}

\section{Concluding comments}

The first objective of this paper was to propose an analytical framework allowing to evaluate the consequences of a market of quota rights in the EU sugar sector. This theoretical framework is based on duality theory in production economics and uses the concept of virtual or shadow price of a rationed good. It takes into accounts the main specificities of the EU sugar sector, i.e., the " $\mathrm{A}$ " and "B" quota regime, the levy mechanism, and the possibility to produce "C" sugar for the world market. We show that the characteristics of the quota market at equilibrium are defined conditionally to the level of the world price and that different cases have to be distinguished in function of the level of this world price. More precisely, we show that the effective price received by producers in the regime of tradable rights is the same for " $\mathrm{A}$ " and "B" quota quantities (i.e., $p_{a}-r_{a}^{*}=p_{b}-r_{b}^{*}$ ) and that this effective price is greater or equal than the world price (i.e., $p_{a}-r_{a}^{*}=p_{b}-r_{b}^{*} \geq p_{c}$ ). Therefore, for sufficiently high levels of the world price, the quota rental rates adjust downward so that $p_{a}-r_{a} \cdot p_{b}-r_{b}=p_{c}$. In such a situation, we show that quota buyers are indifferent between leasing in additional quantities of quota or producing " $\mathrm{C}$ " sugar. This 
conclusion is obtained in a world without uncertainty. Obviously, risk considerations are also an important element for modelling producer behaviour in a tradable quota regime particularly when the world price of sugar is subject to rapid changes over time.

Empirical results show that the implementation of an intercountry market for sugar quota rights in the EU would lead to dramatic changes in production allocation between the different regions and that the reallocation of about $45 \%$ of sugar production would lead to considerable producers' welfare gains. As expected from the theoretical analysis, the greater are buyers' welfare gains the lower is the world price of sugar. Welfare gains of sellers vary only slightly with the world price (at least for "sufficiently low" levels of the world price).

Simulations presented in this paper show that marketable quota rights represent an interesting and profitable evolution of the present European supply control scheme, at least as far as farmers are concerned. However, an important reallocation of production would occur, mainly from the South of Europe to the North. At the limit, production could even disappear in the less efficient areas. Although farmers in these areas would be net gainers from the market, this reallocation towards Northern European countries might raise political obstacles. The risk of destabilising production zones is undoubtedly the main reason which can be advocated for rejecting a market of sugar quota rights at the European scale. Nevertheless, it is always possible for the farmers in these less efficient regions to produce non rationed crops (cereals or oilseeds).

Finally, it is important to remember that a market for sugar quotas in the EU should not be thought independently of the world market situation in so far as our simulation results highlight the high sensitivity of quota market characteristics at equilibrium to the level of the world price. 


\section{References}

Agra-Europe London, various issues.

Alston, J. M. (1981). A note on the effects of non-transferable quotas on supply functions. Review of Marketing and Agricultural Economics, 49: 186-96.

Alston, J. M. (1992). Economics of commodity supply controls. In T. Becker, R. Gray and A. Schmitz eds., Improving Agricultural Trade Performance under the GATT, Wissenschaftsverlag Vauk Kiel KG.

Babcock, B. A. and Foster, W. E. (1992). Economic rents under supply controls with marketable quota. American Journal of Agricultural Economics, 74: 630-37.

Ball, E., Bureau, J. C., Eakin, K. and Somwaru, A. (1993). A supply-response framework with acreage restrictions for modelling European agriculture under the new CAP conditions. Paper presented at the workshop: The Technology of Primary Production, Modelling Agricultural Supply Response for Policy Analysis, The State of the Art, Rennes, July 1-2.

Bureau, J. C. and Butault, J. P. (1992). Productivity gaps, price advantages and competitiveness in agriculture. European Review of Agricultural Economics, 19: 25-48.

Burrell, A. (1989). The microeconomics of quota transfer. In A. Burrell ed., Milk Quotas in the European Community, CAB International, Wallingford, Oxon.

Butcher, W. R. and Heady, E. O. (1963). Negotiable feed grain output quotas: An estimate of marginal value and exchange. Journal of Farm Economics, 45: 780-88.

Confédération Générale de la Betterave (1987). L'économie betteravière en chiffres. Confédération Générale de la Betterave (CGB), Paris.

Cox, P. G. (1987). The case for tradeable milk production quotas: A note. Irish Journal of Agricultural Economics and Rural Sociology, 12: 95-102.

ECA (1991). Rapport spécial 4/91 sur le fonctionnement de l'Organisation Commune du Marché du sucre et de l'isoglucose, accompagné des réponses de la Commission. Journal Officiel des Communautés Européennes, C 290, 7 Novembre 1991.

Erskine, A. and Pugh, L. (1990). The European sugar industry: the sleeping giant awakens. Salomon Brothers, London, March.

Floyd, J. (1965). The effects of farm price supports on the return to land and labor in agriculture. Journal of Political Economy, 73: 148-58.

Fulginiti, L. et Perrin, R. (1993). The theory and measurement of producer response under quotas. Review of Economics and Statistics, 75: 97-106.

Graham, H. E. (1983). Sugar beet supply response in three EEC countries. Institute of Agricultural Economics, University of Oxford, Report 1.

Guyomard, H. et Mahé, L.-P. (1993). Producer behaviour under strict rationing and quasi-fixed factors. University of Minnesota, Economic Development Center, Bulletin Number 93-2.

Guyomard, H., Delache, X., Goudounêche, C. and Mahé, L..-P. (1994). A micro-econometric analysis of milk quota transfer: application to France. Working paper, ENSAR and INRA-ESR, Rennes, France.

Landell Mills (1990). Beet pricing under the European Community sugar regime. Sweetener Analysis, Oxford, May-June.

Leuck, D. and Neff, S. (1991). Potential effects of policy reform on the European Community sugar market. Staff Report AGES9129, Agriculture and Trade Analysis Division, ERS, USDA.

Montgomery, W. D. (1972). Markets in licenses and efficient pollution control programs. Journal of Economic Theory, 5: 395-418.

Morin, L. (1992). Marché européen des quotas sucriers. Mémoires et thèses, 3, INRA-ESR, Grignon, France. 
Moschini, G. (1984). Quota values under price Uncertainty. Canadian Journal of Agricultural Economics, 32: 223-235.

Moschini, G. (1988). A model of production with supply management for the Canadian agricultural sector. American Review of Agricultural Economics, 70: 379-92.

Moschini, G. (1989). Modelling supply response of supply managed industries: a review of issues. Canadian Journal of Agricultural Economics, 70: 379-94.

Neff, S. (1990). National production quotas on milk and sugar: Can they survive the drive for a Single Market? Outlook Report, Western Europe Section, ERS, USDA, 61-66.

Roberts, I. M. and Wish-Wilson, P. (1991). Domestic and world market effects of EC sugar policies. Discussion paper 91-1, Australian Bureau of Agricultural and Resource Economics, Canberra, Australia.

Royson, J. P. (1983). A simple method for evaluating the Shapiro-Francia W test of non normality. The Statistician, 32: 297-300.

Rucker, R. R., Thurman, W. N. and Sumner, D. A.. (1993). The economic effect of restricting the transfer of production rights: a case study of the market of US tobacco quota. Working paper, Department of Agricultural and Resource Economics, North Carolina State University.

Shapiro, S. and Francia, R. (1972). An approximate analysis of variance test for normality. Journal of the American Statistical Association, 67.

Squires, D. (1994). Firm behavior under input rationing. Journal of Econometrics, 61: 235-57.

Von Cramon-Taubadel, S. (1990). The influence of the agri-monetary system on agricultural trade in the EC: the case of sugar. Journal of Agricultural Economics, 41(3): 346-61.

Wong, G., Surgiss, R. and Borrell, B. (1989). The economic consequences of international trade sugar reform. Discussion paper 89-7, Australian Bureau of Agricultural and Resource Economics, Canberra, Australia. 
Table 1. Sugar producer behaviour in the regime of transferable production rights

\begin{tabular}{|c|c|c|c|}
\hline Characterisation & Optimal level of production & $\begin{array}{c}\text { Quota supply }\left(q^{t, n} \leq 0\right) \text { or quota } \\
\text { demand }\left(q^{t, n} \geq 0\right)\end{array}$ & $\begin{array}{l}\text { Cate- } \\
\text { gory }\end{array}$ \\
\hline \multicolumn{4}{|l|}{ First case: $p_{c} \leq C m^{n}(0)$} \\
\hline$p_{h}-r_{b} \leq C m^{\prime \prime}(0)$ & $y^{t, n}=0$ & $q^{t, n}=-\bar{y}_{a+b}^{n}<0$ & $N_{l, i}$ \\
\hline$C m^{n}(0) \leq p_{b}-r_{b} \leq \eta^{n}$ & $y^{i, n} ; C m^{n}\left(y^{i, n}\right)=p_{b}-r_{b}$ & $q^{t, n}=y^{t, n}\left(p_{b}-r_{b}\right)-\bar{y}_{a+b}^{n} \leq 0$ & $N_{1,2}$ \\
\hline$C m^{\prime \prime}(0) \leq \eta^{\prime \prime} \leq p_{h}-r_{h}$ & $y^{\prime, n} ; C m^{n}\left(y^{\prime, n}\right)=p_{b}-r_{b}$ & $q^{t, n}=y^{\prime, n}\left(p_{h}-r_{h}\right)-\bar{y}_{a+h}^{n} \geq 0$ & $N_{1,3}$ \\
\hline \multicolumn{4}{|c|}{ Second case: $C m^{n}(0) \leq p_{c} \leq \eta^{n}$} \\
\hline$p_{c} \leq p_{b}-r_{b} \leq \eta^{\prime \prime}$ & $y^{t, n} ; C m^{n}\left(y^{\prime, n}\right)=p_{b}-r_{b}$ & $q^{t, n}=y^{\prime \prime \prime}\left(p_{b}-r_{b}\right)-\bar{y}_{a+b}^{n} \leq 0$ & $N_{2, I}$ \\
\hline$p_{c} \leq \eta^{n} \leq p_{h}-r_{b}$ & $y^{\prime \prime n} ; C m^{n}\left(y^{\prime \prime n}\right)=p_{b}-r_{b}$ & $q^{i n}=y^{\prime \prime \prime}\left(p_{b}-r_{b}\right)-\bar{y}_{a+h}^{n} \geq 0$ & $N_{2.2}$ \\
\hline \multicolumn{4}{|c|}{ Third case: $\mathrm{Cm}^{n}(0) \leq \eta^{n} \leq p_{c}$} \\
\hline$p_{c}<p_{b}-r_{b}$ & $y^{\prime \prime n} ; C m^{n}\left(y^{\prime \prime \prime}\right)=p_{b}-r_{b}$ & $q^{\prime, n}=y^{\prime, n}\left(p_{b}-r_{b}\right)-\bar{y}_{a+b}^{n}>0$ & $N_{3,1}$ \\
\hline$p_{c}=p_{b}-r_{h}$ & $y^{\prime n} ; C m^{n}\left(y^{\prime, n}\right)=p_{b}-r_{b}=p_{c}$ & $\begin{array}{l}q^{\prime, n}=y^{\prime, n}\left(\left(p_{b}-r_{b}\right)=p_{c}\right)-\bar{y}_{a+b}^{n}> \\
(1)\end{array}$ & $N_{3.2}$ \\
\hline
\end{tabular}

(1) Producers of the $N_{3.2}$ category are indifferent between renting additional "A+B" or producing " $\mathrm{C}$ " sugar for the same amount. We assume that these producers would prefer to rent additional rights. 
Table 2. Main characteristics of sugar beet production in the European Union

\begin{tabular}{|l|c|c|c|c|}
\hline & $\begin{array}{c}\text { Sugar beet production } \\
\text { (in \% of total European } \\
\text { production) }\end{array}$ & $\begin{array}{c}\text { Sugar beet acreage } \\
\text { (in of arable land in } \\
\text { each region) }\end{array}$ & $\begin{array}{c}\text { Yields } \\
\text { (tonne per hectare) }\end{array}$ & $\begin{array}{c}\text { Opportunity cost } \\
\text { (ECU per tonne) }\end{array}$ \\
\hline Belgium & 6.1 & 26.0 & 55.6 & 30 \\
\hline Denmark & 3.3 & 17.0 & 44.1 & 25 \\
\hline Niedersachsen & 7.2 & 21.3 & 48.0 & 29 \\
\hline Nordrhein Westfal. & 4.2 & 19.3 & 49.7 & 24 \\
\hline Hessen & 1.1 & 14.4 & 50.1 & 22 \\
\hline Rheinland Pfalz & 1.3 & 19.1 & 55.1 & 20 \\
\hline Baden Wurttemb. & 1.3 & 15.8 & 54.6 & 23 \\
\hline Bayern & 4.7 & 16.5 & 58.1 & 20 \\
\hline Greece & 2.5 & 24.9 & 63.6 & 32 \\
\hline Castilla Leon & 4.3 & 13.4 & 40.1 & 37 \\
\hline Andalucia & 2.8 & 65.0 & 27.7 & 40 \\
\hline lle de France & 2.7 & 13.6 & 50.5 & 26 \\
\hline Champagne & 5.8 & 10.5 & 63.9 & 22 \\
\hline Picardie & 9.5 & 15.0 & 58.3 & 30 \\
\hline Haute Normandie & 1.6 & 10.4 & 47.0 & 27 \\
\hline Centre & 1.7 & 20.8 & 55.0 & 26 \\
\hline Nord pas de Calais & 4.0 & 15.7 & 54.7 & 30 \\
\hline Lombardia & 1.2 & 21.1 & 54.7 & 50 \\
\hline Veneto & 3.0 & 23.0 & 50.3 & 50 \\
\hline Emilia Romagna & 5.7 & 30.4 & 49.7 & 50 \\
\hline Marche & 1.9 & 29.2 & 46.0 & 49 \\
\hline Puglia & 1.1 & 17.3 & 32.2 & 53 \\
\hline Netherlands & 8.0 & 23.4 & 55.6 & 31 \\
\hline East England & 6.5 & 18.0 & 48.6 & 32 \\
\hline North England & 1.0 & 14.5 & 37.6 & 32 \\
\hline Total & 92.6 & - & - & - \\
\hline No: New Lan & & & \\
\hline
\end{tabular}

Note: New Länder of Germany are not included beause of lack of data. 
Table 3. Effects of the world price of sugar on the prices of sugar beet and on the equilibrium rental rates of "A" and "B" quotas (ECU per tonne)

\begin{tabular}{|lcccc|}
\hline Intervention price & 45.4 & 45.4 & 45.4 & 45.4 \\
World price & 13.5 & 22.5 & 29.0 & 30.5 \\
\hline Price of "A" sugar beet & 44.5 & 44.5 & 44.5 & 44.5 \\
Price of "B" sugar beet & 30.8 & 37.4 & 42.3 & 43.3 \\
Rental rate of "A" quota & 15.3 & 15.3 & 15.3 & 14.0 \\
Rental rate of "B" quota & 1.6 & 8.2 & 13.1 & 12.8 \\
\hline
\end{tabular}


Table 4. Effects of the world price on the EU production of sugar (1000 tonnes)

\begin{tabular}{|c|c|c|c|c|c|c|c|c|c|}
\hline & \multirow[b]{2}{*}{$\begin{array}{l}\text { initial } \\
\text { quota }\end{array}$} & \multicolumn{2}{|c|}{$\begin{array}{l}\text { World price } \\
13.5 \mathrm{ECU} / \mathrm{t}\end{array}$} & \multicolumn{2}{|c|}{$\begin{array}{l}\text { World price } \\
22.5 \mathrm{ECU} / \mathrm{t}\end{array}$} & \multicolumn{2}{|c|}{$\begin{array}{l}\text { World price } \\
29.0 \text { ECU/t }\end{array}$} & \multicolumn{2}{|c|}{$\begin{array}{l}\text { World price } \\
30.5 \mathrm{ECU} / \mathrm{t}\end{array}$} \\
\hline & & $\begin{array}{c}\text { initial } \\
\text { "C" } \\
\text { sugar }\end{array}$ & $\begin{array}{l}\text { final } \\
\text { quota }\end{array}$ & $\begin{array}{l}\text { initial } \\
\text { "C" } \\
\text { sugar }\end{array}$ & $\begin{array}{l}\text { final } \\
\text { quota }\end{array}$ & $\begin{array}{l}\text { initial } \\
\text { "C" } \\
\text { sugar }\end{array}$ & $\begin{array}{l}\text { final } \\
\text { quota }\end{array}$ & $\begin{array}{l}\text { initial } \\
\text { "C" } \\
\text { sugar }\end{array}$ & $\begin{array}{c}\text { final } \\
\text { producti } \\
\text { on }\end{array}$ \\
\hline Belgium & 826 & 0 & 507 & 6 & 507 & 60 & 507 & 71 & 594 \\
\hline Denmark & 425 & 0 & 725 & 146 & 725 & 300 & 725 & 301 & 762 \\
\hline Germany & 2446 & 0 & 3270 & 826 & 3270 & 1245 & 3270 & 1296 & 3558 \\
\hline Greece & 319 & 0 & 133 & 2 & 133 & 21 & 133 & 27 & 168 \\
\hline Spain & 862 & 0 & 329 & 0 & 329 & 78 & 329 & 150 & 460 \\
\hline France & 3140 & 0 & 4391 & 881 & 4391 & 2072 & 4391 & 2287 & 6348 \\
\hline Italy & 1309 & 0 & 151 & 0 & 151 & 0 & 151 & 0 & 208 \\
\hline Netherlands & 872 & 0 & 612 & 4 & 612 & 232 & 612 & 296 & 760 \\
\hline UK & 769 & 0 & 850 & 34 & 850 & 328 & 850 & 444 & 993 \\
\hline $\begin{array}{l}\text { Exchanged } \\
\text { quantity }\end{array}$ & & \multicolumn{2}{|c|}{4947} & \multicolumn{2}{|c|}{4947} & \multicolumn{2}{|c|}{4947} & \multicolumn{2}{|c|}{4026} \\
\hline
\end{tabular}


Table 5. Effects of the world price on quota suppliers' and buyers' surplus variations (million ECU)

\begin{tabular}{|c|c|c|c|c|c|c|c|c|c|c|c|c|}
\hline & \multicolumn{3}{|c|}{ World price: 13.5 ECU/t } & \multicolumn{3}{|c|}{ World price: 22.5 ECU/t } & \multicolumn{3}{|c|}{ World price: 29.0 ECU/t } & \multicolumn{3}{|c|}{ World price: 30.5 ECU/t } \\
\hline & \multirow{2}{*}{$\begin{array}{c}\text { initial } \\
\text { surplus }\end{array}$} & \multicolumn{2}{|c|}{ variation of surplus } & \multirow{2}{*}{$\begin{array}{c}\text { initial } \\
\text { surplus }\end{array}$} & \multicolumn{2}{|c|}{ variation of surplus } & \multirow{2}{*}{$\begin{array}{c}\text { initial } \\
\text { surplus }\end{array}$} & \multicolumn{2}{|c|}{ variation of surplus } & \multirow{2}{*}{$\begin{array}{c}\text { initial } \\
\text { surplus }\end{array}$} & \multicolumn{2}{|c|}{ variation of surplus } \\
\hline & & sellers & buyers & & sellers & buyers & & sellers & buyers & & sellers & buyers \\
\hline Belgium & 10.6 & 5.5 & 0.2 & 10.5 & 5.5 & 0.2 & $10 ; 8$ & 5.5 & 0 & 10.9 & 5.0 & 0 \\
\hline Denmark & 7.0 & 1.5 & 2.1 & 7.3 & 1.5 & 1.8 & 9.1 & 1.5 & 0 & 9.6 & 1.4 & 0 \\
\hline Germany & 41.3 & 8.3 & 10.2 & 44.0 & 8.3 & 7.5 & 51.4 & 8.3 & 0 & 53.4 & 7.7 & 0 \\
\hline Greece & 3.9 & 2.2 & 0.1 & 3.9 & 2.2 & 0.1 & 4.0 & 2.2 & 0 & 4.0 & 1.9 & 0 \\
\hline Spain & 9.2 & 6.1 & - & 9.2 & 6.1 & - & 9.2 & 6.1 & 0 & 9.3 & 5.1 & 0 \\
\hline France & 44.6 & 16.5 & 17.2 & 48.2 & 16.5 & 13.7 & 61.8 & 16.5 & 0 & 65.1 & 15.2 & 0 \\
\hline Italy & 8.2 & 12.7 & - & 8.2 & 12.7 & - & 8.2 & 12.7 & 0 & 7.9 & 10.9 & 0 \\
\hline Netherlands & 9.5 & 6.7 & 0.6 & 9.5 & 6.7 & 0.6 & 10.1 & 6.7 & 0 & 10.5 & 6.0 & 0 \\
\hline UK & 10.3 & 5.5 & 0.7 & 10.3 & 5.5 & 0.7 & 10.9 & 5.5 & 0 & 11.5 & 4.9 & 0 \\
\hline EU & 145.5 & 65.0 & 30.7 & 151.1 & 65.0 & 24.1 & 175.2 & 65.0 & 0 & 182.2 & 58.0 & 0 \\
\hline
\end{tabular}




$$
\forall
$$




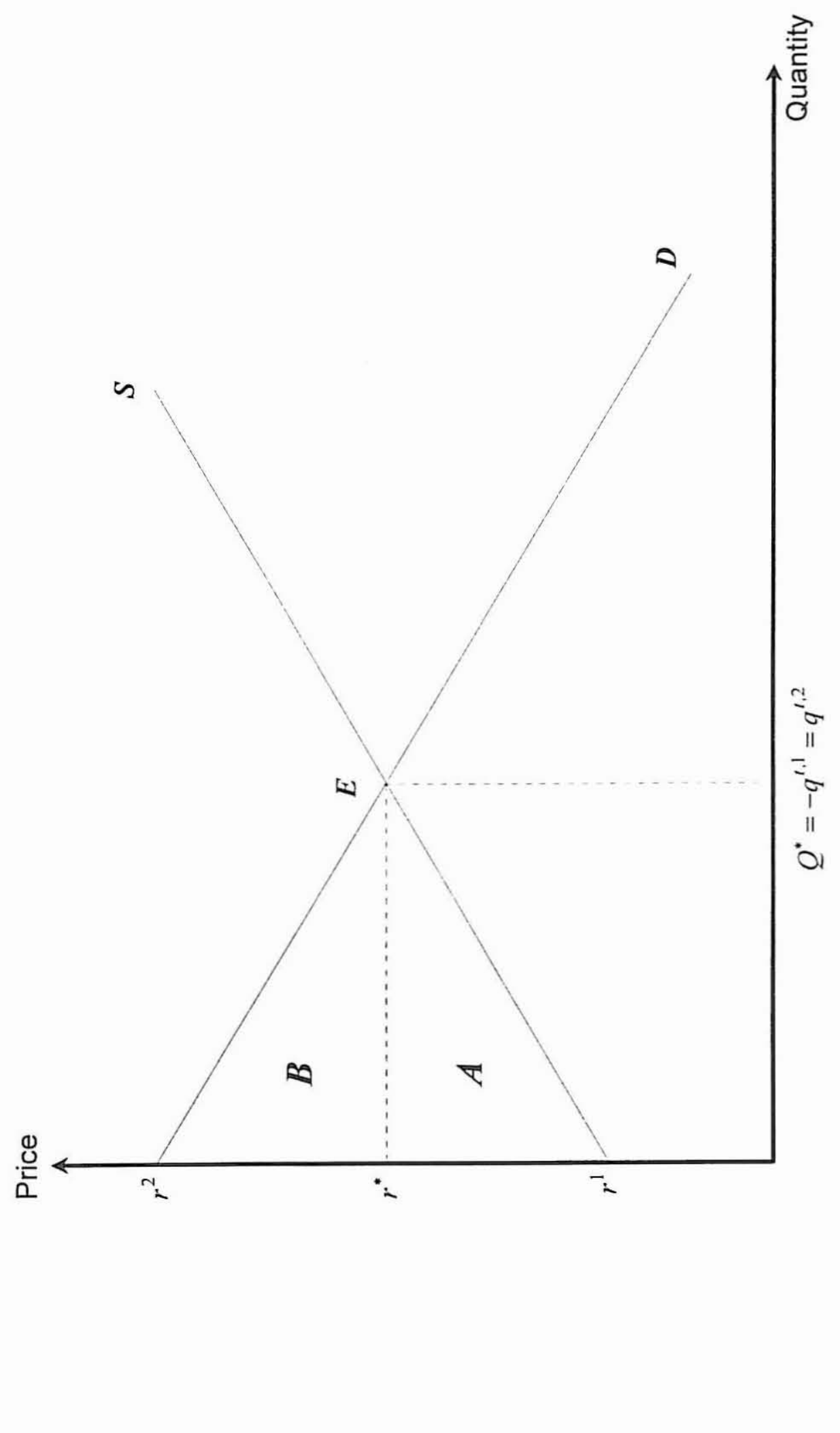




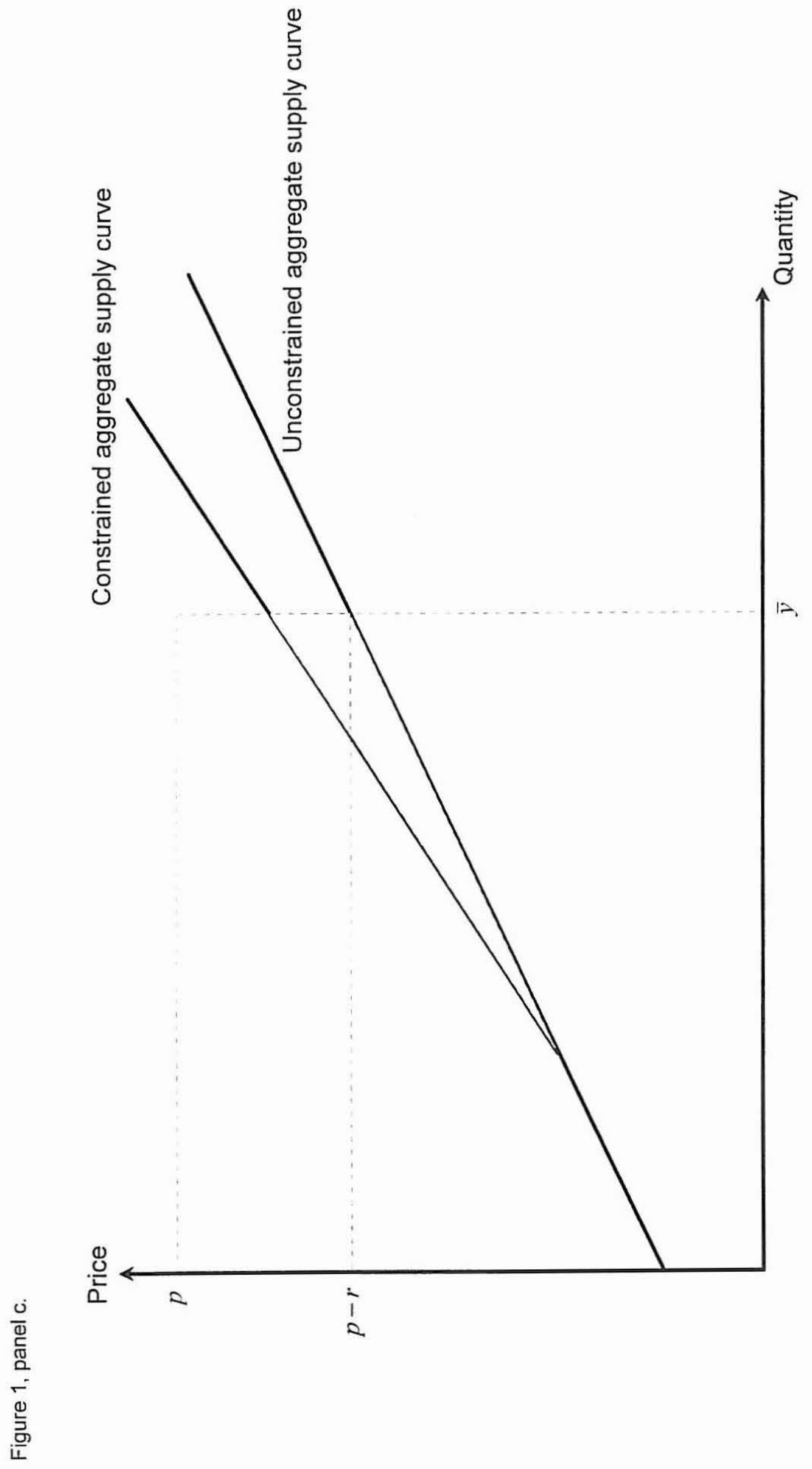




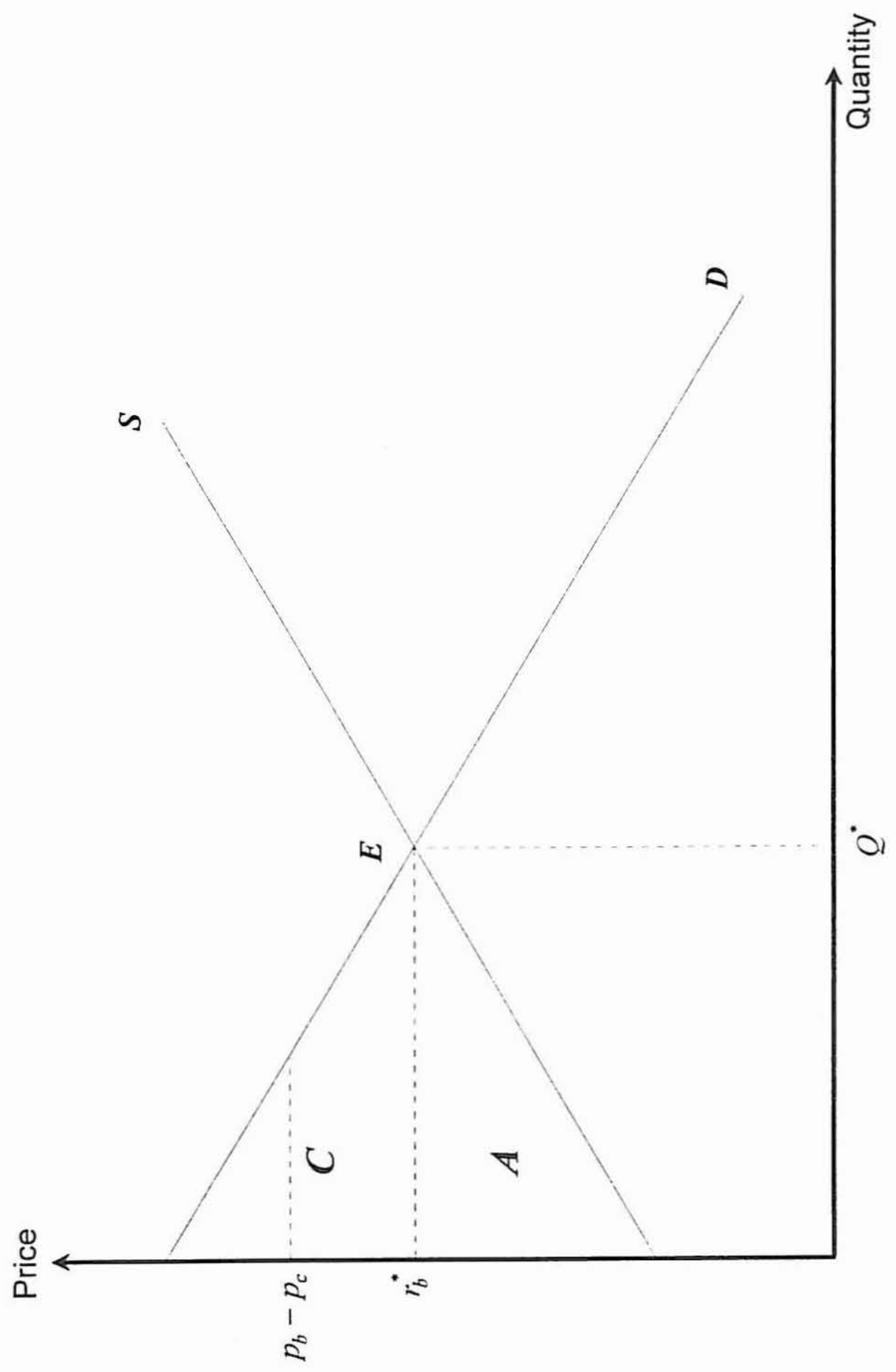

ํㅓㄴ 


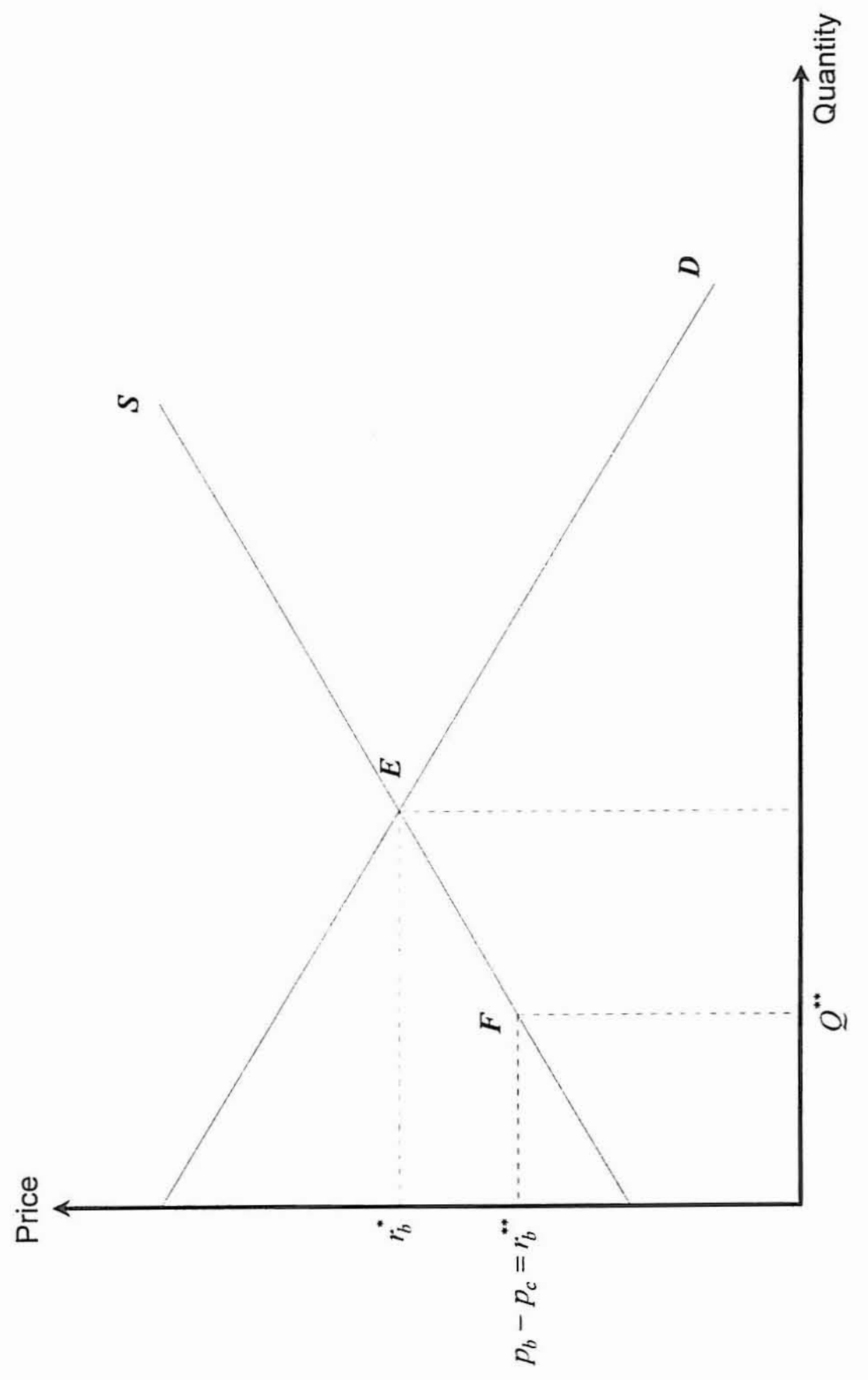

ํㅜㄴ 
$\stackrel{\infty}{N}$

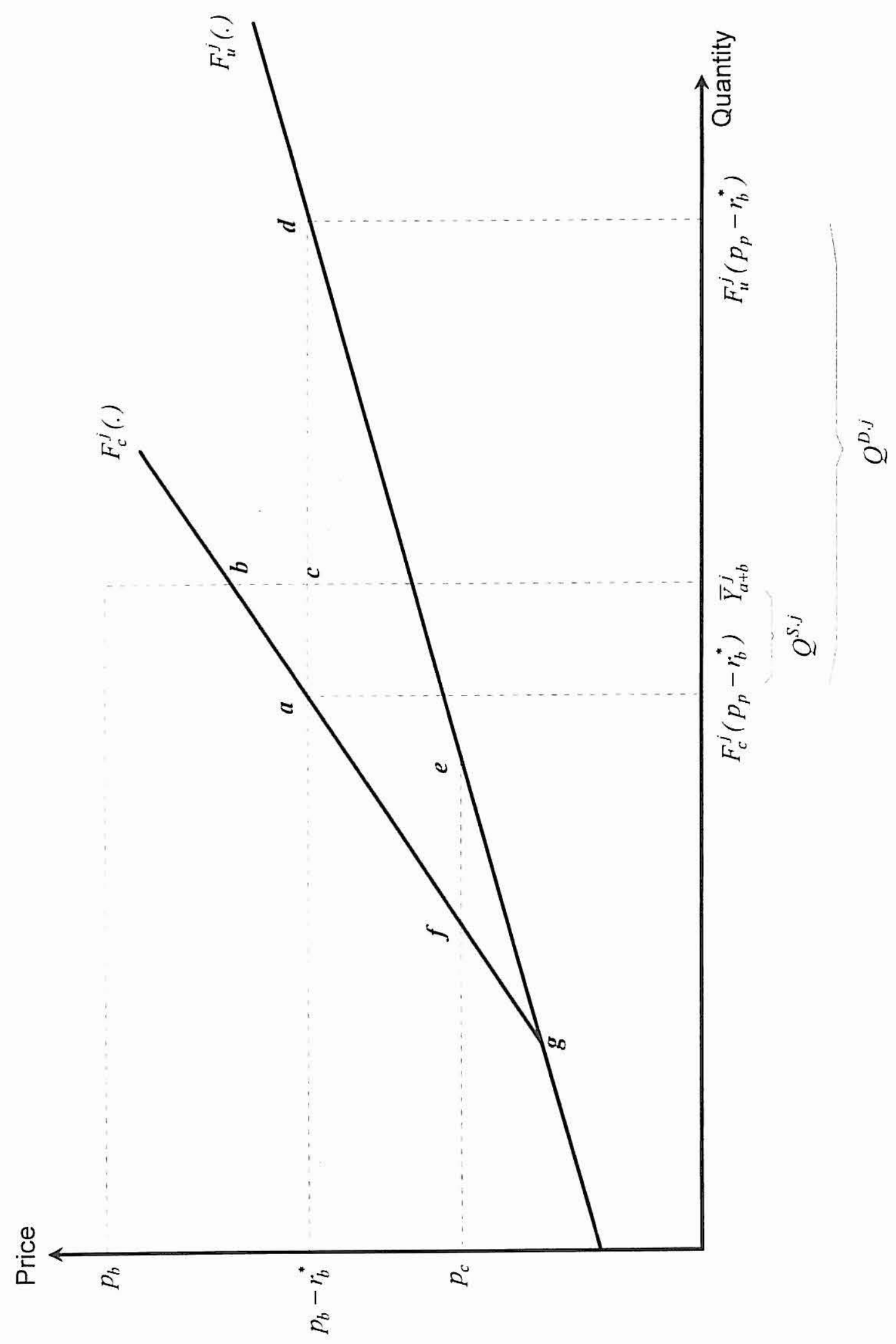

㐫 


\section{Annex 1.}

The first-order necessary conditions for programme (7) are (the two equilibrium rental prices are assumed to be strictly positive):

(8a) $p_{a}-r_{a}^{*}-C m^{n}\left(y^{\prime \prime \prime}\right)+\delta_{a}^{n}=0$

(8b) $p_{b}-r_{b}^{*}-C m^{n}\left(y^{\prime \prime \prime}\right)+\delta_{b}^{n}=0$

(8c) $p_{c}-C m^{n}\left(y^{\prime, \prime}\right)+\delta_{c}^{n}=0$

(8d) $y_{i}^{\prime, n} \delta_{i}^{n}=0 ; y_{i}^{\prime, n} \geq 0 ; \delta_{i}^{n} \geq 0 ; i=a, b, c$

Proposition. If "A" and "B" quotas are constraining for each producer $n$, then i) $p_{a}-p_{b}<r_{a}^{*}$, ii) $p_{a}-p_{b}=r_{a}^{*}-r_{b}^{*}$, and iii) $p_{a}-r_{a}^{*}=p_{b}-r_{b}^{*} \geq p_{c}$.

Proof of part $i$ ) of the proposition. Let us assume that $r_{a}^{*} \leq p_{a}-p_{b}$. First-order conditions (8a) and (8b) imply that $p_{a}-r_{a}^{*}=p_{b}-r_{b}^{*}+\delta_{b}^{\prime \prime}-\delta_{a}^{n} ; \forall n=1, \ldots, N$. This equality cannot be satisfied if the farmer produces " $\mathrm{A}$ " and "B" sugar in the regime of tradable rights because in such a case, $\delta_{a}^{n}=0, \delta_{b}^{n}=0$ and hence, $p_{a}-r_{a}^{*}=p_{b}-r_{b}^{*}$ which contradicts the assumption that $r_{a}^{*} \leq p_{a}-p_{b}$ since $r_{b}^{*}>0$. In the same way, the equality cannot be satisfied if each farmer produces "B" sugar only because in such a case $p_{a}-p_{b}<r_{a}^{*}$. Finally, the equality cannot also be satisfied if each farmer produces "A" sugar only because in that case each producer is willing to lease out all of his "B" quota endowment, but the aggregate demand for "B" quota equals zero and there is no equilibrium on the "B" quota market. Hence, $r_{a}^{*}>p_{a}-p_{b}$.

Proof of part ii) of the proposition. Let us assume that $p_{a}-p_{b}<r_{a}^{*}-r_{b}^{*}$. Under this assumption, conditions $(8 \mathrm{a})$ and $(8 \mathrm{~b})$ may be satisfied only if each farmer does not produce "A" sugar in the regime of tradable rights (i.e., $\delta_{a}^{n}=0$ ). In such a case, each farmer is willing to lease out all of his of "A" quota endowment, but the corresponding demand for "A" quota equals zero and there is no equilibrium on the "A" quota market. By a similar reasoning, one shows that if $p_{a}-p_{b}>r_{a}^{*}-r_{b}^{*}$, then each farmer is willing to lease out all of his "B" quota endowment and there is no equilibrium on the "B" quota market. Hence, $p_{a}-p_{b}=r_{a}^{*}-r_{b}^{*}$.

Proof of part iii) of the proposition. Let us assume that $p_{a}-r_{a}^{*}=p_{b}-r_{b}^{*}<p_{c}$. In such a case, one easily verifies that each producer is willing to lease out all of his initial "A+B" quota endowment and that there is no equilibrium on the quota market. Hence, $p_{a}-r_{a}^{*}=p_{b}-r_{b}^{*} \geq p_{c}$. 


\section{Annex 2.}

Consistent econometric estimates of sugar supply functions in the EU have been proved to be difficult to obtain because of the cumbersome modelling of the specific features of the sugar regime. The inconsistency of the estimates presented in the literature suggests that parametric approaches perform quite poorly in accounting for the three price level system ${ }^{12}$. In cases of complex constrained production with several price levels, linear programming (LP) models have performed better than standard econometric techniques. The derivation of supply response curves from activity models seems thus to be a satisfactory alternative to parametric estimates of supply. It is this approach we have followed to construct regional supply curves of sugar.

In the regions where farm business association data were available, regional supply curves are estimated by stacking individual LP models of producers who maximise gross margins. The models include a technical constraint on the maximum percentage of land that can be used for producing beets as well as individual quotas (for more details on the construction of these LP models, see Morin, 1992).

The practical problem we faced was the lack of micro-economic data for several regions. The solution to this problem was, i) to estimate supply curves using LP firm models for the regions where detailed data were available, ii) to fit a parametric function that relates the opportunity or marginal cost of sugar to the cumulated production on the basis of the results of these models, and iii) to calibrate the distribution function for the regions were data were scarce using more aggregate information.

The opportunity cost of sugar beet production corresponds to the dual variable associated to the "A+B" quota constraint in the LP models. This opportunity cost is therefore a function of gross margins of alternative productions. Individual opportunity costs and individual levels of beet production were used as pseudo-data for the fitting of a parametric function specific to each region. Firms were ranking according to their opportunity cost, and the regional supply curves were obtained by plotting the cumulated production on the $Y$ axis and the opportunity cost on the $X$ axis. Henri's graphs suggested that the curve obtained for each region could be approximated by a lognormal distribution. A Shapiro-Francia test (Shapiro and Francia, 1972 ; Royson, 1983) confirmed that the lognormal distribution could not be rejected. In other words, for regions $j$ where detailed data were available, we estimate the regional supply functions by:

$$
F^{j}(p)=A^{j} H\left(\frac{\log \left(p-p_{o}^{j}\right)-m^{j}}{\sigma^{j}}\right)
$$

where $A^{j}$ is the maximum supply of sugar beets in region $j$ (i.e., the quota level in the non tradable quota regime and the maximum production in the tradable quota regime), $H$ is the cumulated function of the normal distribution, and $p_{o}^{j}, m^{j}$ and $\sigma^{j}$ are region $j$ specific parameters to be calibrated. 
For regions $k$ where data were not available to estimate individual models, the opportunity cost of land was first estimated by the gross margin of the most likely substitutable crop to sugar beets. The opportunity cost of sugar beets was then approximated by the sum of the variable costs of beets and the opportunity cost of land (divided by yields in beets). The first empirical moment of the opportunity cost of sugar beets was calculated using the Farm Accountancy Data Network. It gave an estimate of mean $\mathrm{m}^{k}$. The variance $\sigma^{k}$ was estimated by assuming that the ratio $m^{k} / \sigma^{k}$ is constant and equal to $0.18^{13}$. The economic interpretation of the intercept $p_{0}^{k}$ is the value of the opportunity cost of production for a zero supply of beets. It was therefore approximated by the variable costs of sugar beets in the average farm of the relevant region. 


\section{Endnotes}

1 Although comparative advantages are not easy to measure, several studies suggest that some
European countries are much less efficient than others in producing sugar. Bureau and Butault (1992)
show that the quantity of goods and services used to produce a given amount of sugar beet is much lower
in France and Germany than in other European countries, while it is much higher in Italy, Greece and
Ireland. Others studies (Erskine and Pugh 1990 ; Landell Mills, 1990) also lead to close conclusions and
show considerable discrepancies in costs of production across European countries. Evidence suggests
that the present allocation of production shows little connection with comparative advantages of the
different production areas (Roberts and Whish-Wilson, 1991). There is no evidence that the present
allocation of production corresponds to any comparative advantages in the processing sector either.
Countries which are less efficient in beet production do not show a particular comparative advantage in
transformation infrastructures and technology (Morin, 1992). Landell Mills (1990) shows that processing
costs are very similar among European countries.

${ }^{2}$ Agra-Europe London (1987, updated April 92) provides detailed information on national aids. As an example, aids generate a support to beet growers up to $35 \%$ above the EU level in Italy (sum of "adaptation aids" and storage subsidies).

${ }^{3}$ In order to simplify the presentation of the basic model, we assume that, i) all producers face the same output price, and ii) all producers continue to produce a positive level of output in the regime of tradable quota rights.

${ }^{4}$ The comparative statics of output supply, at both the firm and industry level, and of traded quantity can also be derived. The most interesting result is that these quantities are invariant with respect to changes in output price. This can easily be verified by noting that output supply is a function of the difference $p-r^{*}$ and that $\partial r^{*} / \partial p=1$.

5 In order to simplify the presentation of the theoretical model, we consider the case of a mono production of sugar. The analysis may easily be generalised to a multi-output technology (where other outputs are not controlled by production quotas and hence, free to adjust) by replacing the cost function $C^{n}\left(y^{n}, w, \bar{Z}^{n}\right)$ by the restricted profit function $\pi\left(y^{n}, p^{-}, w, \bar{Z}^{n}\right)$ where $p^{-}$denotes the price vector of other products.

${ }^{6}$ However, it is clear that welfare effects of the quota market have to be analysed by distinguishing " $\mathrm{A}$ " and "B" quotas and the two corresponding output prices, $p_{a}$ and $p_{h}$.

${ }^{7}$ Alternative formulations for producers' surplus variations may be obtained using directly supply and demand functions for quota rights.

${ }^{8}$ It is worth remembering that $p_{b}-r_{b} \geq p_{c}$. One verifies that $W_{d}^{j}$ is a decreasing function of $p_{c}$, for a given $r_{b}<p_{b}-p_{c}$, and that $W_{d}^{j}=0$ when $p_{b}-r_{b}=p_{c}$.

${ }^{9}$ The regional capacity constraint $K_{j}$, corresponds to a full utilisation of plant capacities without new investments.

10 The price of beets is obtained by transforming the price of sugar in beet equivalent, minus processing costs.

${ }^{11}$ We use two stars to represent the equilibrium rental rates of "A" and "B" quotas in the case where the world price of sugar is strictly greater than 29.0 ECU per tonne to ensure the consistency with the notations used in section 2 .

12 Long-term elasticities of sugar supply in the various Member States of the EU range between 0.1 and 2 (Graham, 1983 ; Wong et al., 1989 ; Leuck and Neff, 1991). Ball et al. (1993) find short-term elasticities varying between 0.1 and 1.6 , depending on countries. In most cases, the fit of the model is very poor.

${ }^{13}$ In the regions where farm business association data were available, the ratio $m^{j} / \sigma^{j}$ is equal to $0.18+/-0.02$. 


\section{DOCUMENTS DE TRAVAIL}

Juillet 1995

90-01 L'IMPACT DE LA PROPOSITION AMERICAINE AU GATT SUR LES AGRICULTURES DE LA CEE ET DES USA. Hervé GUYOMARD, Louis-P. MAHE, Christophe TAVERA (1990).

90-02 AGRICULTURE IN THE GATT : A QUANTITATIVE ASSESSMENT OF THE US 1989 PROPOSAL. Hervé GUYOMARD, Louis-P. MAHE, Christophe TAVERA (1990).

90-03 EC-US AGRICULTURAL TRADE RELATIONS : DO POLITICAL COMPROMISES EXIST ? Louis-P. MAHE, Terry L. ROE (1990).

90-04 ANALYSE MICRO-ECONOMIQUE DE L'EXPLOITATION AGRICOLE. Catherine BENJAMIN (1990).

90-05 PSE, AMS AND THE CREDIT FOR SUPPLY MANAGEMENT POLICIES IN THE GATT NEGOTIATIONS (application to the EC case). Hervé GUYOMARD, Louis-P. MAHE (1990).

90-06 COMPLETING THE EUROPEAN INTERNAL MARKET AND INDIRECT TAX HARMONIZATION IN THE AGRICULTURAL SECTOR. HEIVÉ GUYOMARD, LOUIS-P. MAHE (1990).

90-07 ALIMENTATION ANIMALE ET DYNAMIQUE DES PRIX DES MATIERES PREMIERES SUR LE MARCHE FRANCAIS. Yves DRONNE, Christophe TAVERA (1990).

91-01 ECONOMIC BEHAVIOUR OF AGRICULTURAL HOUSEHOLDS: IMPLICATIONS OF ASSUMING PERFECT SUBSTITUTABILITY BETWEEN LABOURS. Catherine BENJAMIN, Hervé GUYOMARD (1991).

91-02 LIMITATION DES IMPORTATIONS EUROPEENNES DE SUBSTITUTS DES CEREALES : IMPACT BUDGETAIRE ET DE BIEN-ETRE ECONOMIQUE. Chantal LE MOUEL (1991).

91-03 L'EVOLUTION DE LA POLITIQUE AGRICOLE COMMUNE ET SON IMPACT SUR LES PRODUCTIONS ET REGIONS AGRICOLES FRANCAISES. HeIvé GUYOMARD, Yves LEON (1991).

91-04 PUBLIC INPUTS, ALLOCATABLE FIXED FACTORS AND THE THEORY OF THE MULTIPRODUCT FIRM : A CLARIFICATION. Hervé GUYOMARD (1991).

91-05 LA REFORME DE LA PAC : Une révolution ou un grand pas dans la bonne direction ? Hervé GUYOMARD, Louis-P. MAHE (1991).

92-01 LA POLITIQUE AGRICOLE COMMUNE DANS L'ETAU DE L'URUGUAY ROUND. Hervé GUYOMARD, Louis-P. MAHE (1991).

92-02 TRADE COMPROMISES BETWEEN THE EC AND THE US : An Interest Group - Game Theory Approach. Martin JOHNSON, Louis-P. MAHE, Terry L. ROE (1992).

92-03 LE PROJET Mac SHARRY : facteurs de sensibilité du débouché céréalier communautaire. Hervé GUYOMARD, Louis-P. MAHE (1992). 
92-04 JOINT DECISION IN LABOUR SUPPLY AND DEMAND BEHAVIOUR : AN ANALYSIS OF FRENCH AGRICULTURAL HOUSEHOLDS. Catherine BENJAMIN, Hervé GUYOMARD (1992).

92-05 MODELE DE TRANSMISSION DES PRIX GARANTIS DE CEREALES DANS LA COMMUNAUTE ECONOMIQUE EUROPENNE : DEVELOPPEMENTS THEORIQUES ET APPLICATION A LA FRANCE. Yves SURRY (1992).

92-06 IMPORT TARIFFS, DOMESTIC DISTORTIONS AND "MARKET LINKAGES". Chantal LE MOUEL (1992).

93-01 CONSEQUENCES DE LA REFORME DE LA PAC SUR L'AGRICULTURE BRETONNE. Anne-Marie PELHERBE (1992).

93-02 LA REFORME DE LA PAC ET LES NEGOCIATIONS DU GATT - QUELLE COMPATIBILITE ? Hervé GUYOMARD, Louis-P. MAHE (juin 1992).

93-03 THE EC AND US AGRICULTURAL TRADE CONFLICT AND THE GATT ROUND : PETTY MULTILATERALISM ? Hervé GUYOMARD, Louis-P. MAHE, Terry L. ROE (1993).

93-04 DECISIONS DE TRAVAIL DES MENAGES AGRICOLES FRANCAIS. Catherine BENJAMIN, Alessandro CORSI, Hervé GUYOMARD (1993).

93-05 PSE AND DISTORTING AGGREGATE MEASURE OF SUPPORT IN THE CONTEXT OF PRODUCTION QUOTAS. Hervé GUYOMARD, Louis-P. MAHE (1993).

93-06 IS A PRODUCTION QUOTA PARETO SUPERIOR TO PRICE SUPPORT ONLY? HEIVÉ GUYOMARD, Louis-P. MAHE (1993).

93-07 PRODUCER BEHAVIOUR UNDER RATIONING WITH TRADABLE RIGHTS. HeIVÈ GUYOMARD, Louis-P. MAHE (1993).

93-08 CALCUL DES ELASTICITES PRIX ET REVENU SOUS HYPOTHESE DE BUDGETISATION PAR ETAPES : une méthode approchée. Alain CARPENTIER, Hervé GUYOMARD (1993).

94-01 LA REFORME DE LA PAC ET LES NEGOCIATIONS DU GATT. Perspectives pour l'agriculture française et communautaire. Hervé GUYOMARD, Louis-P. MAHE (1993).

94-02 L'OFFRE DE TRAVAIL DES FEMMES. Application à l'agriculture française. Catherine BENJAMIN, Hervé GUYOMARD et Michel SOLLOGOUB (1994).

94-03 LA NOUVELLE INSTRUMENTATION DE LA POLITIQUE AGRICOLE COMMUNE. Hervé GUYOMARD et Louis-P. MAHE (1994).

94-04 A NOTE ON THE ESTIMATION OF PRICE FUNCTIONS. Ludo PEETERS et Yves SURRY (1994).

94-05 A MICRO-ECONOMETRIC ANALYSIS OF MILK QUOTA TRANSFER: APPLICATION TO FRANCE. Xavier DELACHE, Hervé GUYOMARD, Louis-P. MAHE, Xavier IRZ (1994).

94-06 ANALYSE MICRO-ECONOMIQUE D'UN MARCHE DES DROITS A PRODUIRE: APPLICATION AUX QUOTAS LAITIERS EN FRANCE. Xavier DELACHE, Catherine GOUDOUNECHE, Hervé GUYOMARD, Louis-P. MAHE, Xavier IRZ. (1994).

94-07 TENDERS FOR EUROPEAN CEREAL EXPORT REFUNDS: A STRUCTURAL APPROACH, Jean-Marc BOURGEON, Yves LE ROUX (1994). 
94-08 MODELLING A SIPHON ON QUOTA TRANSFERS : APPLICATION TO MILK IN FRANCE, Hervé GUYOMARD, Louis-P. MAHE (1994).

94-09 FARM HOUSEHOLD PRODUCTION IN THE PRESENCE OF RESTRICTIONS ON DEBT: THEORY AND POLICY IMPLICATIONS, Euan PHIMISTER (1994).

94-10 FARM HOUSEHOLD PRODUCTION UNDER CAP REFORM: THE IMPACT OF BORROWING RESTRICTIONS (1994), Euan PHIMISTER (1994).

95-01 QUOTA MOBILITY IN THE EUROPEAN SUGAR REGIME. Jean-Christophe BUREAU, Hervé GUYOMARD, Laurent MORIN and Vincent REQUILLART (1995). 
